\title{
AZ EURÓPAI PROFESSZIONÁLIS LABDARÚGÓKLUBOK MŰKÖDÉSI MODELLJEINEK ELEMZÉSE
}

\author{
ANALYSIS OF THE BUSINESS MODELS OF THE EUROPEAN \\ PROFESSIONAL FOOTBALL CLUBS
}

\begin{abstract}
A professzionális labdarúgás üzleti és sportszakmai eredményei mentén elemezték a szerzők az UEFA egyes tagországainak az első osztályú bajnokságaiban érdekelt élklubok stratégiai mintázatait. Egy 54 labdarúgóklubból álló mintán a klubok teljesítményét három nagy dimenzió mentén vizsgálták meg, amelyek a következők: a pénzügyi teljesítmény, a pályán elért eredmények és az (emberi)erőforrás-gazdálkodás/átigazolási politika dimenziói. Hierarchikus klaszterelemzést végeztek el, amely alapján négy csoportba sorolták az egyes klubokat. Ez a négy klaszter a következő: 1. nemzetközi elit, 2. kihívók, 3. feltörekvő bajnokok, 4. versenyben maradásért küzdők. A kutatás fő eredménye, hogy az azonos klaszterbe tartozó sportvállalkozások hasonló mennyiségü jövedelmet állítanak elő, azonos mértékben sikeresek a hazai bajnokságban, és hasonló az átigazolási politikájuk, egymástól azonban markánsan eltérnek az egyes klaszterek.
\end{abstract}

\section{Kulcsszavak: labdarúgás, professzionális sport, stratégiák, klaszterelemzés}

The authors analysed with regard to the professional football markets the strategic patterns of the leading clubs participating in the first division leagues of UEFA's member countries. In a sample of 54 clubs, the performance of clubs was examined along three major dimensions: financial performance, sport performance and human resource management/ transfer policy dimensions. They performed a hierarchical cluster analysis based on the classification of the clubs into four groups. These four clusters are: 1. International Elite; 2. Challengers; 3. Emerging Champions; and 4. Struggling for Competitiveness. The authors' main findings suggest that sports companies belonging to the same cluster generate a similar amount of income, are equally successful in the domestic leagues and have similar transfer policies, although each cluster differs markedly from the others.

Keywords: football, professional sports, strategies, cluster-analysis

\section{Finanszírozás/Funding:}

A szerzők a tanulmány elkészítésével összefüggésben nem részesültek pályázati vagy intézményi támogatásban.

The authors did not receive any grant or institutional support in relation with the preparation of the study.

\section{Szerzők/Authors:}

Kocsis Bence, sporttudományos elemző, Magyar Labdarúgó Szövetség, (kocsis.bence@mlsz.hu)

Dr. Kiss Csaba, egyetemi adjunktus, Budapesti Corvinus Egyetem, (csaba.kiss@uni-corvinus.hu)

A cikk beérkezett: 2020. 10. 07-én, javítva: 2020. 12. 22-én, elfogadva: 2021. 01. 12-én.

This article was received: 07. 10. 2020, revised: 22. 12. 2020, accepted: 12. 01. 2020.

$\mathrm{N}$ apjainkban a labdarúgóklubok sikerét már nem kizárólag a pályán elért eredményekből vezethetjük le, hanem az üzleti eredményeik tekintetbevétele is elengedhetetlen. A két szempont komplex célrendszert jelöl ki (András, 2003). A hazai és nemzetközi szakirodalomban is élénk figyelem övezi a labdarúgóklubok versengésének keretet adó országos és nemzetközi futball-ligáknak (Terrien \& Andreff, 2020) és maguknak a labdarúgókluboknak a stratégiáit és ezek fejlődését (Kuper, 2009; Franck, 2010; Barajas \& Rodriguez, 2010). Jelen cikkünkben ez utóbbi témára fókuszálunk. Szabados (2003) jelen folyóirat hasábjain elméleti-logikai alapon kategorizálta a klubok ál- tal követett stratégiákat, amelyet András \& Havran (2015) aktualizált és továbbfejlesztett. Intuitívan azt hihetnénk, hogy Európa meghatározó élklubjainál a prudens gazdálkodás legalább akkora fontosságú, mint a labdarúgópályán elért kiemelkedő sporteredmény. Mind több kutatás mutat rá azonban arra, hogy a sportsikerek hátterében olykor fenntarthatatlan gazdasági folyamatok, tervszerütlen gazdálkodás, észszerütlen erőforrás-bevonás húzódik meg (Franck \& Lang, 2014). Az Európai Labdarúgó Szövetségek Egyesülete (UEFA) a 2004/2005-ös szezon elején bevezette a klublicenc rendszerét a pénzügyi fegyelem fokozása érdekében. Ez sportszakmai, infrastrukturális, 
emberi erőforrást illető, jogi és pénzügyi kritériumokat támasztott az UEFA nemzetközi versenysorozataiba nevezni kívánó klubokkal szemben. Egyes klubok mind erőteljesebb és az üzleti racionalitástól elváló pénzügyi erőforrástöbblete újabb lépéseket kívánt: a 2010-es évek elején a „pénzügyi fair play” (FFP) szabályrendszerének (Union of European Football Associations, 2018) életre hívását indukálta (Peeters \& Szymanski, 2014), a „pénzügyi dopping” visszaszorítását célzandó (Franck, 2014).

Mindezen fejlemények a klubok üzleti modelljét sem hagyták érintetlenül, ami a stratégiák deduktív elemzésén túl a stratégiák empirikus, kvantitatív adatokon alapuló kategorizálásának aktualitását jelöli ki. Jelen tanulmányunkban arra teszünk kísérletet, hogy a sportszakmai és az üzleti dimenziót számszerű adatok révén megragadva, statisztikai módszerekkel csoportosítsuk Európa legjobb futballklubjainak müködési modelljeit, reményeink szerint hozzájárulva a téma elméletének és gyakorlatának fejlesztéséhez.

Cikkünk felépítése az alábbi: először áttekintjük a téma hazai és nemzetközi szakirodalmát, majd bemutatjuk a módszertant, kiemelten a vizsgálati modellt és a kutatásba bevont változókat és azok operacionalizálását. Ezt követően az eredményeinket közöljük, majd elemezzük az egyes stratégiatípusokat és következtetéseket fogalmazunk meg, kitérve a kutatás korlátaira és továbbfejlesztési lehetőségeire.

\section{Elméleti háttér}

A kutatás elméleti felvezetésének elején a professzionális futballklubok müködési kontextusát, az ebből fakadó stratégiai és operatív sajátosságokat mutatjuk be, különös tekintettel a játékjogok piacára és ennek a stratégiai emberierőforrás-menedzsmenttel való kapcsolatára.

A professzionális labdarúgóklubok a labdarúgó iparágban müködő üzleti vállalkozások, amelyek a legtöbb esetben valamilyen gazdasági társaságként müködnek (ezt később még árnyaljuk). A továbbiakban a labdarúgóklubokat olyan szervezettekként értelmezzük, amelyek üzletszerű működésre törekednek a labdarúgó iparágban. Üzletszerű müködésről akkor beszélhetünk, ha müködési kiadásaikat a müködésük szempontjából releváns piacokról beszerzett bevételekkel kívánják fedezni a (sport) vállalkozások.

András (2003) és András \& Havran (2015) csoportosításában a legfőbb piacok, amelyeken a labdarúgóklub jelen van és ezáltal a fö bevételi források egy labdarúgóklub esetében a következőek: jegy- és bérletbevételek, közvetítési jogokból származó bevételek, kereskedelmi jogok bevétele, játékosértékesítés bevétele. Az UEFA számviteli szempontok alapján csoportba rendezi a fentebb felsorolt bevételtípusokat. Az első hármat, vagyis a jegy- és bérletbevételek (angol megjelölésben gate receipts revenue), valamint a közvetítési jogokból (broadcasting) és kereskedelmi jogokból (sponsorship and merchandising) származó bevételeket együttesen egyszerüen bevételeknek vagy (és ez a meghatározóbb) müködési bevételeknek nevezik. E bevételek mögött egyértelműen a fogyasztó áll, és ezek a bevételek egymástól sem függetlenek, hiszen az a klub, amelynek több szurkolója van, az vélhetően több jegyet tud értékesíteni, jó eséllyel többen fogják nézni a TV-ben és valószínűleg több, a klubhoz kapcsolódó tárgyat képes eladni.

A másik nagy kategória a bevételeken belül a játékosértékesítésből szármató bevétel. A játékosok játékjoga vagyoni értékü jogként szerepel a labdarúgó-vállalkozások könyveiben, így e jogok értékesítése egyéb bevételként, míg ilyen jogok vétele egyéb ráfordításként jelentkezik az eredménykimutatásaikban. Emiatt ezek közvetlenül nem hatnak a müködési eredményre, viszont közvetetten annál inkább. E hatás részletesebb bemutatására a különböző stratégiatípusoknál kerül sor a későbbiekben. Ezeken kívül a labdarúgóklubok rendelkezhetnek egyéb forrásokból származó bevételekkel, amelyek például eredhetnek a stadion egyéb üzleti hasznosításából. Azonban ezek elemzése számos okból kifolyólag gátakba ütközik. Az egyik ok lehet, hogy a klubok a legtöbb esetben a beszámolóikban csak a fentebb felsorolt hármas bontásban tüntetik fel a bevételeiket, és kevés szó esik az egyéb bevételekről. Emellett - példánknál maradva - a stadion üzleti hasznosításából származó bevételek mérése azért sem könnyü, mert e létesítmények üzemeltetését számos esetben nem a klub végzi, hanem kiszervezik azt, azaz egy erre szakosodott szervezet müködteti. A szervezet egy meghatározott öszszeget fizet a sportvállalkozásnak, akik cserébe átengedik a szervezés és a stadion üzleti hasznosításának a jogait.

Amikor a labdarúgóklubok működéséről beszélünk, fontos szót ejteni egy olyan sajátosságról, amely más iparágakra kevéssé jellemző. András (2003) alapján megállapítható, hogy ezen típusú vállalkozások müködésének a meghatározó jellegzetessége, hogy kettős, időnként egymásnak ellentmondó célrendszerrel rendelkeznek. Egyik oldalon megjelenik a fenti bevételekre építő gazdasági eredményességre vonatkozó cél, mivel elméleti síkon a tulajdonosok joggal várnak el a befektetésüktől jövőbeli megtérülést. A másik cél ezzel párhuzamosan a sportbéli eredményesség, hiszen a klubok szurkolói fogyasztói élményének immanens része a sportsiker átélése. Szabados (2003) szemléletes cikkben mutatta be az előző évtizedben ennek a két célnak az egymáshoz való akkori viszonyát. Ezek alapján a szerző 4+1 különböző stratégiatípust határoz meg, amelyek a következők: sikerkör-stratégia, amelynek egyik alrendszere a transzferstratégia; kereskedelmi stratégia; szinergiastratégia; l'art pour l'art stratégia.

A sikerkör-stratégia esetében a futballklub eredményesége vonzza maga után a bevételeket, így a gazdasági hasznot, amit visszaforgatnak a még jobb játékosok megszerzésébe. Egy önerősítő folyamatban a labdarugóklub stratégiai emberierőforrás-befektetéssel a klub játékerejének maximalizálásra törekszik, abban a reményben, hogy ennek sikeressége az eredményes gazdasági müködés zálogát jelenti majd. Emberierőforrás-menedzsment szempontból itt a kiválasztásra és a teljesítményértékelésre tevődik a hangsúly, hiszen a klubok olyan kész játékosokat szeretnének az egyesületükben tudni, akik illeszkednek a taktikai elképzeléseikbe és azonnal tudják az eredmények szállítani, és akik pedig nem válnak be szakmailag, azokkal szerződést bontanak. 
A sikerkör-stratégia altípusa a transzferstratégia, itt a fő cél a minél jobb képességű utánpótláskorú játékosok kiválasztása, képzése, felkészítése és segítése, annak érdekében, hogy minél jobb felnőtt korú játékosokká váljanak. Ezt követi e fiatal játékosok játékjogainak értékesítése, és az így kapott pénz egy része a tulajdonos haszna lehet, míg a másik részét újra befekteti infrastrukturális és egyéb fejlesztésekbe. Reich és Szabados (2000) alapján a labdarúgásban a munkaerőpiac beszállítóinak is nevezhetjük ezeket a klubokat.

A következő stratégiatípus a kereskedelmi stratégia, amelyről az mondható el, hogy az alapvető cél a közvetlen nyereségelérés és ez magasabb prioritású, mint a sportszakmai eredményesség. A fó cél a sportélmény leválasztása a teljes fogyasztói élményről, és magas szintü kiegészítő szolgáltatások nyújtása, valamint a költséghatékony müködés, mivel a klub játékosállománya nem képes kiemelkedő sportszakmai sikerek elérésére.

A szinergiastratégia esetében a futballklub nem törekszik közvetlen nyereségre. A tulajdonos nem közvetlenül kíván nyereséget elérni a klubon, hanem a klub működése által más területeken szeretne előrelépést felmutatni (más vállalkozásainak a nyereségéhez, politikai ambícióihoz stb.).

A l'art pour l'art sajátos stratégiát takar. A legfontosabb a klub imázsának és hagyományainak a fenntartása, és ezért a klubvezetők hajlandóak komoly anyagi áldozatot is hozni. Erre remek példa a Real Madrid vagy Barcelona, amelynek nincsenek is valós tulajdonosai, pusztán csak tagjai (socios) és nem is gazdasági társaságként, hanem egyesületként müködnek.

A két cél közti, megfelelö egyensúly megtalálása nem magától értetődő feladat, az elmúlt évtized fejleményei jelentősen árnyalják ezt a kettős célrendszert, és ez nem független a tulajdonosi struktúrától. Tulajdonosi szempontból két nagy modell különíthető el egymástól a labdarúgás területén, amelyek a két végletet reprezentálják. Az egyik az ,üzleti alapú”, míg a másik az ,állami alapú” modell (András, 2003). Utóbbi esetében a finanszírozó az állam, ebben az esetben nincs valós tulajdonos, és a bevételek nem jelentenek valós korlátot. Ilyenkor a sport a közhangulat javítását és a politikai rendszer legitimálását szolgálja. A másik modell esetében a bevételek föbb része az üzleti szférától érkezik, van valós tulajdonos, aki - elméletben - érdekelt a befektetése megtérülésében, a bevételek tényleges korlátot jelentenek az egyesület számára, és a szolgáltatás a szórakoztató iparág részeként üzemel. Ez a típusú modell jellemző a nyugat-európai bajnokságok klubjaira. Franck (2010) tovább árnyalja az, „üzleti alapú modell'-t, a tulajdonosi struktúra alapján, amikor megkülönbözteti az egy többségi tulajdonos magántulajdonában levő klubokat, a részvénytársaságok által müködtetett klubokat és az egyesületeket, amelyek a tagok összessége által formált jogi személyiségek. A magánbefektetők megjelenésének jellemző formáit Rohde és Breuer (2017) tovább árnyalta. Kategóriarendszerük alapján öt csoport figyelhető meg az európai labdarúgásban: 1: sportegyesületi keretek, magánbefektető nélkül, 2: gazdasági társasági forma, 100\%-ban sportegyesületi tulajdonban, magán- befektető nélkül, 3: gazdasági társasági forma, kisebbségi magánbefektetőkkel, 4: gazdasági társasági forma, többségi tulajdonosi szerepben levő belföldi magánbefektetövel/befektetőkkel, 5: gazdasági társasági forma, többségi tulajdonosi szerepben levő külföldi magánbefektetővel/ befektetökkel.

A rendelkezésre álló anyagi erőforrások tekintetében az egy többségi tulajdonos magántulajdonában levő klubok versenyelőnyben lehetnek, amikor az emberi eröforrásba való befektetési döntések gyorsasága és a befektetések nagysága határozza meg a játékjogokhoz való hozzáférési lehetőséget. Amolyan „sugar daddy”-ként viselkednek sokszor ezek a klubtulajdonosok (Kuper, 2009), és klubjaiknál emiatt fokozódhat a jövőbe való, anyagi befektetés (Franck, 2010; Lang, Grossmann, \& Theiler, 2011), amely akár túlzó méretüvé is válhat. Ezt „overinvestment"-nek nevezi Grossmann (2015). Ezzel párhuzamosan növekedhet a klub adósságállománya, és akár veszteségessé is válhat (Storm \& Nielsen, 2012; Alaminos \& Fernández, 2019). A magánbefektetéseknek tehát versenytorzító hatásuk is lehet (Franck \& Lang, 2014), erre reagálva az UEFA az ún. Financial Fair Play (FFP) szabályrendszerének életre hívásával igyekezett ennek hatásait csökkenteni (Franck, 2014; Peeters \& Szymanski, 2014; Schubert \& Hamil, 2018). Az FFP ugyanakkor egyes kutatások szerint nem csökkentette, hanem növelte az egyenlőtlenségeket az európai futball színpadán. A pénzügyi stabilitás ugyanis a bevételekhez illeszkedő kiadásokat feltételez, tehát a jelentős bevételekhez nagy humán erőforrást illető befektetések (pl. bérköltségek) társulhatnak a top klubok esetén, a kis klubok bérköltségeinek plafonját pedig kijelöli a bevételeik korlátozott nagysága. Ez konzerválhatja a kisebb klubok versenyhátrányát és szükítheti stratégiai mozgásterüket (Garcia-del-Barrio \& Rossi, 2020).

A befektetések fókuszában főként a játékjogok állnak. Piaca igen speciális szegmense a munkaerőpiacnak, röviden játékospiacként szokás hivatkozni rá. András (2003) definíciója alapján ez egy olyan speciális munkaerőpiac, ahol a csere tárgya a (labdarúgó) játékjoghasználatának átruházása egy meghatározott időre. A játékjog egy olyan vagyoni értékü jog, amely magába foglalja az adott sportoló fizikai és szellemi képességeinek összességét. A játékjog használati joga átruházható a labdarúgóklubra a kötött szerződés időtartamára, viszont ennek lejárta után ez visszaszáll a sportolóra. A játékjog használati jogát a szerződés ideje alatt a klub átengedheti más klubnak egy bizonyos időre vagy végleg, amennyiben ehhez a sportoló is hozzájárul, viszont ebben az esetben az átadó vállalat bizonyos kompenzációra, úgynevezett átigazolási díjra tarthat igényt.

Az átigazolási díj a sport egy kuriózuma, és András (2003) szerint kialakulása alapvetően két dologgal magyarázható. Egyrészt azzal, hogy az utánpótláskorú játékosok képzésével foglalkozó sportszervezetek ebből tudják fenntartani magukat, másrészt a nagyobb sportvállalatok is ebből tudják pénzügyi szempontból is müködőképessé tenni saját szervezetük életét. Ennek következtében azt mondhatjuk, hogy az átigazolási piacon egy-egy új játé- 
kos játékjogának a megvásárlása komoly emberierőforrás-befektetési döntést jelenthet (András \& Havran, 2015). Annál is inkább, hiszen a játékjog megszerzése számottevő bértömeg lekötését is jelentheti. Itt tetten érhető egy átváltás a két cél között, hiszen egy „drága” játékjog megvásárlása, illetve az ezzel járó addicionális bérköltség az üzleti eredményesség rovására növelheti a sportági eredményességet.

A bevételek és a kiadások áttekintése után figyelmünket fókuszáljuk a profitra. A többségi tulajdonosi szerepbe kerülő egyszemélyi magánbefektetők között szemléleti különbségre utalva Rohde és Breuer (2016) megkülönbözteti a hasznosságmaximalizáló, a győzelemmaximalizáló és a profitmaximalizáló klub(tulajdonosi) filozófiát. Az UEFA a jelentéseiben kétféle profittípust különböztet meg. Az első a működési eredmény (operating profit vagy underlying profit), amely azt mutatja meg, hogy mekkora a jövedelemtermelő képessége a sportvállalkozásoknak. Ha ez a szám pozitív, vagyis a müködési eredménye alapján profitot realizált a vállalkozás, akkor azt el tudja költeni az átigazolási piacon új játékosok játékjogainak a megszerzése érdekében. Ha ez a szám negatív, akkor játékosok jogainak értékesítéséből kell fedezni a müködési eredmény hiányát, hogy ne legyen veszteséges a vállalkozás. A végső eredmények összehasonlításának a lehetőségére a riportokban az adózott eredmény szolgál (net profit after tax vagy bottom-line profit). Nagy valószínüséggel azon klubok lesznek a nettó költők vagy felvásárlók a piacon, melyek müködési eredményei pozitívak, (olyan klubok, melyek nagyobb összegért vesznek, mint amennyiért adnak el a játékjogokat), és őket nevezhetjük a sikerkör-stratégiát megvalósítani igyekvő kluboknak. Emberierőforrás-stratégiájukban a kiválasztásra helyezik a hangsúlyt. Míg azon klubok, melyek müködési eredményei negatívak, lesznek az eladók, akik többért értékesítenek, mint amennyiért vásárolnak az átigazolási piacon, annak érdekében, hogy ki tudják egyensúlyozni eredményüket. Stratégiájuk alapján őket a transzferstratégiát megvalósító klubok közé sorolhatjuk, és emberierőforrás-stratégiájukban a képzés-fejlesztésen van nagyobb hangsúly.

A stratégiák közötti törésvonalakra vonatkozó trendek mind markánsabbak (András \& Havran, 2016), ugyanakkor a szakirodalomban a különböző stratégiatípusok elválasztása gyakran deduktívan, elméleti alapon történt. A közelmúltban már történt kísérlet olyan empirikus vizsgálatra, amely bizonyos dimenziók kvantifikálása és statisztikai módszerekkel történő elemzése révén igyekezett feltárni egyes stratégiatípusok jelenlétét a professzionális futballklubok között (Sener \& Karapolatgil, 2015). Jelen tanulmányunkban mi is erre teszünk kísérletet.

\section{Módszertan}

\section{Kutatási kérdés}

Kutatásunkban arra kerestük a választ, hogy empirikus adatok statisztikai elemzését követően milyen stratégiai mintázatok figyelhetők meg Európa elit labdarúgóklubjainál a sportszakmai célok és a gazdasági célok prioritása mentén.

\section{Általános megfontolások}

Annak érdekében, hogy általános képet kaphassunk az európai labdarúgó klubok helyzetéről, az Európai Labdarúgó Szövetség (UEFA) által kibocsátott Klub Licenc Jelentés (Club Licencing Benchmarking Report) részletes elemzését választottuk (UEFA, 2019b). Ezekben a riportokban rendelkezésre állnak historikus adatok nemzeti ligákra összesítve az egyes bevételtípusokról vagy éppen a kiadásokról. E dokumentumok elemzésével ki lehet választani azokat a bajnokságokat, amelyek klubjai érdemesek mélyebb vizsgálódásokra.

Az elemzésnél külön-külön megvizsgáltuk, hogy az egyes ligákban miként alakult a jegy- és bérletértékesítésből, szponzorációból és a közvetítési jogdíjakból származó bevétel, valamint az átigazolási kiadások és a bérköltségek az adott időszakban. Az elemzett kategóriákból egyértelmüen kimagaslott a Premier League. Az angol első osztályt a spanyol La Liga követte, amelytől már valamelyest elmaradt a német Bundesliga 1. és az olasz Serie A. Ezen országok első osztályú bajnokságaitól jelentősen elmaradt a francia, a holland, a portugál és a török első osztályú bajnokság, de e négy nemzet legjobb klubjai még így is kiemelkedtek az UEFA 55 tagországának más klubjai közül. Ezért a további vizsgálódásunkat e nyolc ország első osztályú klubjain végeztük. A klubok pontos listáját és ennek összeállítási megfontolásait a következő fejezetben mutatjuk be.

A mintába került klubok működését három fö dimenzió mentén vizsgáltuk. Az egyik a pályán nyújtott teljesítmény, a másik a pénzügyi eredmények dimenziója (e dimenzió mutatószámait szezonokra bontva a KPMG Tanácsadó $\mathrm{Kft}$. sporttanácsadási részlege bocsátotta a rendelkezésünkre, így nekünk csak az egy szezonra vetített átlagszámítást kellett elvégeznünk). Ezt a dimenziót még kiegészítettük a klubok különböző internetes platformokon (Facebook, Twitter, Instagram és Youtube) nyújtott „teljesítményével”. Ezek az adatok a 2020.10.01-jei állapotokat tükrözik. A harmadik nagy dimenzió az egyes klubok erőforrás-gazdálkodását érinti.

Ezt követően ezen adatok alaposabb áttekintése következett. Ehhez először a PowerBI, majd mélyebb statisztikai elemzéshez az SPSS statisztikai programot használtuk. Egy az euklideszi távolságon alapuló, centroid módszerrel végrehajtott hierarchikus klaszterelemzésen beül három, a stratégiaalkotás sportszakmai és üzleti szempontjából releváns változó (átlagos pontszám a hazai bajnoki mérkőzéseken, transzferegyenleg, valós jövedelemtermelö képesség) mentén kerültek a különböző klaszterekbe a klubok. Az adatokat a klaszterelemzés lefuttatása előtt standardizáltuk. A hierarchikus klaszterelemzés dendrogramja a 2. ábrán látható.

A négy nagy klaszter átlagértékeit radardiagram (4. ábra) segítségével tudtuk vizualizálni, így rámutatni az eltérő klaszterbe tartozó klubok különböző működési modelljeire.

\section{A minta összetétele}

A kutatás folyamán első lépésként meg kellett határoznunk, hogy az alapsokaságból mely klubokat szeretnénk 
részletesen vizsgálni. A lista összeállításakor fontos szempont volt az, hogy minden sportvállalkozás esetében minél nagyobb mennyiségü adat legyen elérhető a lehető legszélesebb körü vizsgálódáshoz. A végső minta összesen 54 klubot tartalmaz nyolc különböző bajnokságból, amelyek a következöképpen oszlanak meg:

- 11 klub az angol Premier League-ből,

- 10 klub a spanyol La Liga-ból,

- 14 klub az olasz Serie A-ból,

- 6 klub a német Bundesliga 1-ből,

- 4 klub a francia Ligue 1-böl,

- 3 klub a portugál Liga NOS-ból,

- 3 klub a holland Eredivisie-ből és

- 3 klub a török Süper Ligből.

Az első négy bajnokság esetében azok a klubok szerepelnek a listában, akik az elmúlt öt idényt (2014/2015-töl 2018/2019-ig) végig az első osztályban töltötték. Ez alól kivétel Németország, mert bár a VfL Wolfsburg, a Bayer 04 Leverkusen és az 1. FSV Mainz 05 mind az öt szezont az első osztályban töltötte, kimaradt a listából, mert az esetükben nem érhetők el a pénzügyi kimutatásaik. Rajtuk kívül az Eintracht Frankfurt és a Borussia VfL 1900 Mönchengladbach pénzügyi jelentése elérhető, de az egyes bevételtípusokat nem részletezik, ezért e klubok sem képezik részét a vizsgálódásunknak. A vizsgálódás kezdetének azért lett a 2014/2015-ös szezon meghatározva, mert öt vizsgált idény átlagából egy jóval árnyaltabb és objektívebb képet kaphatunk az egyes klubok müködéséről, azzal szemben, ha csak egy szezont vizsgálnánk. A megfigyelési időszak vége pedig az a szezon, amelyre az egyes sportvállalkozások legfrissebb pénzügyi kimutatásai elérhetők. A maradék négy ligából pedig a legmeghatározóbb klubokat gyüjtöttük össze. Így került a listába többek között Franciaországból az AS Monaco vagy a Paris SG, Hollandiából az Ajax Amsterdam, Portugáliából a Sporting Club de Portugal vagy a Porto, míg Törökországból a Besiktas JK.

A holland, portugál, francia és török liga kisebb klubjai jelentős részben adathiány miatt maradtak ki a kutatásból.

\section{A kutatásba bevont változók}

Az adatgyüjtés kezdete előtt meghatároztuk azokat a változókat, amelyeket a kutatási modellünkbe bevontunk. Annak érdekében, hogy minél teljesebb körü képet kaphassunk a klubok működéséről, három fő irányt jelöltünk ki, amelyek mentén megragadtuk a sportvállalkozások müködését. Ahogy korábban azt bemutattuk, a sportvállalkozások specialitása, hogy kettős célrendszerrel rendelkeznek, azaz gazdasági és sportszakmai dimenzióban egyaránt értelmezendő a stratégiájuk. Ebből következik, hogy olyan mutatók mentén érdemes összevetni a különböző klubok teljesítményét, amelyekkel e két dimenzió jól megragadható. Emellett, mivel a labdarúgóklubok kulcseröforrásait az emberi erőforrás, kiemelten a sportolók, a játékosok adják, ezért olyan mutatókat is szükségesnek tartottunk megjeleníteni a modellünkben, amelyekkel az egyes klubok emberierőforrás-gazdálkodását lehet mérni. Ez utóbbi fogalmat a kutatás folyamán úgy értelmeztük a labdarúgóklubok esetében, mint a játékosok játékjogainak adásvételét, az ehhez kapcsolódó kiadások, bevételek, valamint a játékosbérekre fordított kiadások nagyságát. Ebböl kifolyólag azt mondhatjuk el, hogy a három nagy dimenzió, amelyek mentén az adatgyüjtés és az elemzés megtörtént az egyes kluboknál:

- a gazdasági eredményesség,

- a pályán elért sikeresség, valamint

- az emberierőforrás-gazdálkodás mutatói.

Minden dimenzióhoz tartozó mutató az elmúlt öt szezon (2014/2015-től 2018/2019-es szezonig) átlagát tartalmazza, melyek részletesebb bemutatása az ezt követő alfejezetekben található meg.

\section{A gazdasági eredményesség}

Kutatásunkban az egyes klubok teljesítményét e dimenzió esetében a következő változók bevonásával határoztuk meg:

- Az adott klub valós jövedelemtermelö képessége, azaz a közvetitési jogdijakkal csökkentett árbevétel: A közvetítési jogdíjak jelentős bevételt tesznek ki a labdarúgóklubok életében, ám a közvetítési jogdíjakból származó bevételekre nincsen közvetlen hatással az adott sportvállalkozás. Ha az adott klub teljes bevételéből levonjuk a közvetítési jogdíjakból származó tételeket, akkor egy olyan mutatót kapunk, amely megmutatja az adott sportvállalkozás valós jövedelemtermelö képességét. Ahhoz azonban, hogy rendelkezésünkre álljon ez a mutatószám, össze kell gyüjtenünk az adott klub árbevételét és a közvetítési jogdíjakból származó bevételeket is. A változót öt szezon átlagában vizsgáltuk.

- A játékostranszferek elötti (üzleti) eredmény: Ez a változó azt mutatja meg, hogy miként gazdálkodik a klub a lehetöségeivel, és rá van-e szorulva arra, hogy a játékosainak az értékesítése révén tegye rentábilissá vállalkozásának a müködését. Azon klubok, amelyek üzleti eredménye pozitív, vissza tudják forgatni a profitjukat új játékosok megszerzésére, és őket nevezhetjük az átigazolási piac nettó felvásárlóinak. Ezzel szemben azok a klubok, melyek üzleti eredménye a könyveik alapján negatív, arra kényszerülnek, hogy eladják legjobbjaikat, és így tegyék müködőképessé a vállalkozásukat. E klubokat nevezhetjük az előbb említett piac eladóinak, vagy beszállítóinak. Mindemellett ebből a mutatószámból tudunk következtetni a Szabados (2003) által is bemutatott stratégiatípusokra (sikerkör- és transzferstratégia). Fontos megjegyezni, hogy ez a változó nem tartalmazza a játékosokkal kapcsolatos átigazolási költségeket, hiszen a játékjog vagyoni értékű jogként szerepel a sportvállalkozások, így eladásuk és vételük egyéb bevételként és ráfordításként jelentkezik a klubok könyveiben. A változót öt szezon átlagában vizsgáltuk.

- Social media követők száma: Ez a változó azt ragadja meg, hogy az egyes klubok hogyan teljesítenek a különböző szociális hálókon. Ezen internetes platfor- 
mok jelentőségét a barcelonai székhellyel is rendelkező, Johan Cruyff Intézet is kiemelte egy 2018-as tanulmányában (Johan Cruyff Institute, 2018). Szerintük azért érdemes ezzel foglalkozni, mert azok a klubok, amelyek erősek a különböző social media platformokon több vásárlót tudnak elérni, nagyobb nemzetközi figyelem vetül rájuk, ennek következtében pedig jobb alkupozícióban vannak például az új szponzorációs szerződéseik tárgyalásakor. A kutatásunkban az egyes klubok Facebook, Twitter, Instagram és Youtube követőinek a száma (ez nyilvános adat, a vonatkozó felületen leolvasható) révén operacionalizáltuk ezt a változót. A követőszámok adott napra vonatkoznak, és a végső elemzésnél a négy felület összesített értékével kalkuláltunk.

\section{A pályán elért sikeresség}

E dimenzión belül két mutatószám mentén értékeltük a klubok a teljesítményét:

- Az átlagosan meccsenként szerzett pont nagysága a hazai bajnokságban: E változóval jól lehet mérni az egyes klubok teljesítményét a saját, hazai bajnokságukban. Azért az átlagos meccsenként szerzett pontot (angolul point per game) választottuk ki mutatószámként, mert ezzel összehasonlíthatóvá válnak a különbözö bajnokságok klubjai. Itt figyelembe vettük, hogy ha nem használnánk vetítési alapként a mérkőzések számát, akkor például a német klubok hátránnyal indulnának, hiszen náluk tizennyolc klubos a bajnokság, szemben a többi nagy ligával, ahol húsz klub küzd egymással a végső győzelemért. (Németországban a teljes megszerezhető pont 102, szemben például a Franciaországban megszerezhető 114-gyel.) Így viszont minden klub értéke 0-3 között helyezkedik el (teljes pontszám elosztva a meccsek számával, ahol a győzelem három, a döntetlen egy, az elvesztett mérkőzés pedig nulla pontot ér), ezáltal direktben összehasonlíthatóvá válnak a különböző bajnokságok egyes klubjainak eredményei. Mindazonáltal ezekből az adatokból csak a hazai bajnokságban nyújtott teljesítményre tudunk következtetni. A változót öt szezon átlagában vizsgáltuk.

- Az egyes klubok UEFA koefficiense: Szükségét láttuk olyan mutatószám figyelembevételének is, amellyel jól mérhető, hogy a klubok a nemzetközi kupaküzdelmekben milyen sikeresen szerepelnek. Az UEFA által, az egyes klubok nemzetközi kupákban elért eredményei alapján transzparensen kiosztott együtthatók, az ún. koefficiensek jelentik ebböl a szempontból az összehasonlítás alapját (Union of European Football Associations, 2019a). Minél több győzelmet aratnak az egyes klubok, annál nagyobb koefficiensre tudnak szert tenni az adott kiírásban. Az UEFA koefficienst öt szezon aggregált értékeként jelenítettük meg.

Ezzel a két mutatóval átfogó képet kaphatunk a klubok teljesítményéről mind a hazai bajnokságot, mind a nemzetközi kupákat (Bajnokok Ligáját és Európa Ligát) illetően.

\section{A játékosokkal mint kulcserőforrásokkal való gazdálkodásához kapcsolódó mutatók}

A megfelelő emberierőforrás-gazdálkodás jelentős kihívást jelent a sportvállalkozások vezetőinek, hiszen a játékosok (akik az egyes klubok kulcserőforrásait testesítik meg) megszerzése és megtartása jelentős kiadást jelent az egyesületek számára. Ebből fakadóan az emberierőforrás-gazdálkodás alapján kirajzolódhatnak különböző mintázatok az egyes kluboknál, amelyek alapján elválhatnak a müködési modelljeik.

E dimenzión belül a következő változók mentén értékeltük a klubokat:

- Újonnan érkezők játékosok száma: Ez a változó azt mutatja meg, hogy egy átigazolási időszakban hány új játékost igazoltak az egyes klubok. Erre az adatra azért van szükség, hogy láthassuk, miként tekint a fluktuációra az adott egyesület, hiszen a keretekben szereplő játékosok száma korlátozott. Feltételezhetően lesznek olyan klubok, akik inkább a stabilitásra törekszenek, míg mások a gyors játékosáramlásban látják a siker zálogát. A változót öt szezon átlagában vizsgáltuk.

- Átigazolási egyenleg: Ennek a változónak ez értékéből szintén az egyes klubok startégiáira tudunk következtetni. Az átigazolási egyenleg alapján megkülönböztethetünk beszállító és felvásárló klubokat. Azok a kluboknak, akik több pénzért adnak el játékosokat, mint amennyiért vesznek, az egyenlegünk pozitív, meg ellenkező esetben negatív lesz. A változót öt szezon átlagában vizsgáltuk.

- A bérköltség: A bérráfordítás nagysága jelentős magyarázóerejü az egyes klubok végső helyezéseire a tabellán, ezért érdemes részletesen is vizsgálni. A változót öt szezon átlagában elemeztük.

\section{Az adatgyüjtés menete}

Minden változó vonatkozásában a 2014/2015-ös idénytől a 2018/2019-es szezon átlagában vettük figyelembe az adatokat, kivéve kettő esetében. Az egyik a közösségimédia-követők száma, amelyek a 2020.10.01-jei helyzetet és a négy platform (Facebook, Twitter, Instagram és YouTube) összesített követőszámait mutatják. A másik az UEFA koefficiense, mely mutató esetében az elmúlt öt szezon aggregált pontszámát jelenítettük meg. A gazdasági eredményességhez kapcsolódó mutatószámok adatait a KPMG Tanácsadó Kft. sporttanácsadói részlege biztosította a kutatás számára. A legtöbb klub beszámolójában a pénznem az euró, viszont az angol egyesületek ez alól kivételt képeznek, hiszen ök fontban vezetik könyveiket. Az adatbázisban azonban minden érték euróban van megadva. Az angol klubok esetében is erre lettek átváltva az összegek, melyekhez mindig az adott szezon június 30 . és július 1 . napján érvényben lévő font/euró árfolyamátlagát használták.

A klubok közösségimédia-követőinek számait az egyes klubok hivatalos oldalairól gyüjtöttük össze. A sportvállalkozások múltbéli eredményeit a hazai bajnokságot illetően a worldfootball.net internetes portálról, míg a nemzetközi szereplésükről az UEFA hivatalos webolda- 
láról gyüjtöttük ki. Az átigazolásokkal kapcsolatos adatokat a transfermarkt.de-ről importáltuk, amely jelenleg a legnagyobb online, bárki számára elérhető, labdarúgással kapcsolatos adatbázis. Az adatkörök összefoglalását az 1. táblázat mutatja. pában kevésbé, Észak-Amerikában annál inkább népszerübb, ahol átlagosan 4605363 ember követi a mintában szereplő klubokat. A negyedik vizsgált felületen, a YouTube-on, egy klubot átlagosan 949711 ember követett az adott napon. Ezek alapján azt mondhatjuk el, hogy egy

\section{A kutatásba bevont változók részletei}

\begin{tabular}{|c|c|c|c|}
\hline Változó neve & Megfigyelés időtartama & Forrás & Gyüjtés időpontja \\
\hline Új érkezök átlagos száma & 2014/2015-töl 2018/2019-ig & transkfermarkt.de & 2020.11 .10 \\
\hline Átlagos transzferegyenleg & 2014/2015-töl 2018/2019-ig & transkfermarkt.de & 2020.11 .10 \\
\hline Átlagos meccsenént szerzett pont & 2014/2015-töl 2018/2019-ig & worldfootball.net & 2020.11 .10 \\
\hline UEFA klub koefficiens & 2014/2015-töl 2018/2019-ig & uefa.com & 2020.11 .10 \\
\hline Átlagos teljes bevétel & 2014/2015-töl 2018/2019-ig & KPMG Football Benchmark & 2020.10 .22 \\
\hline Atlagos közvetítési jogdijakból származó bevétel & 2014/2015-töl 2018/2019-ig & KPMG Football Benchmark & 2020.10 .22 \\
\hline Valós jövdelemtermelö képesség & 2014/2015-től 2018/2019-ig & KPMG Football Benchmark & 2020.10 .22 \\
\hline Átlagos üzleti eredmény & 2014/2015-től 2018/2019-ig & KPMG Football Benchmark & 2020.10 .22 \\
\hline Total követök & Adott napi állapot & KPMG Football Benchmark & 2020.10 .01 \\
\hline
\end{tabular}

Forrás: saját szerkesztés

\section{Eredmények}

\section{Leíró statisztikák}

Ami az emberierőforrás-gazdálkodást dimenzióját és annak mutatószámait illeti, öt év átlagát vizsgálva a klubok átlagosan kicsivel kevesebb, mint 8 (7,97) játékost igazoltak szezonként. A transzferegyenlegről azt mondhatjuk el öt szezon átlagát vizsgálva, hogy átlagosan 10,19 millió euróval költöttek többet a klubok, mint amennyiért eladtak játékjogokat. A bérráfordítás átlagosan 126,9 millió eurót tett ki a vizsgált időszak átlagában.

A klubok pályán nyújtott teljesítményét két dimenzió mentén értékeltük. Az első a hazai bajnokságban elért átlagosan meccsenként szerzett pont, amely a mintában szereplő klubok átlagában 1,75 pont volt. A klubok UEFA-koefficiens értékei, amellyel a nemzetközi kupákban való eredményes szereplést lehet mérni, átlagosan 51074 pontban realizálódtak a minta átlagában.

Ami a klubok gazdasági eredményességét illeti, egy átlagos sportvállalkozás teljes árbevétele az öt év átlagában 209,3 millió euró volt. Ebből átlagosan 98,50 millió eurót tett ki a hazai közvetítési díjakból befolyó jövedelem. Ezek alapján azt mondhatjuk el, hogy egy klub átlagos valós jövedelemtermelő képessége 110,86 millió euró a minta átlagában. Fontos megemlíteni még, hogy az átlagos üzleti eredménye a mintán szereplő kluboknak az öt szezon átlagában 18,29 millió eurót tett ki.

A minta alapján azt mondhatjuk, hogy az egy klubra vetített átlagos követőszám a Facebookon a legmagasabb, hiszen itt a követök száma 14648166 fö volt az adott napon. Ezt követi az Instagram, ahol ez adat már csak 9463 662 fö. Harmadik helyre szorult a Twitter, amely Euró- klubot a négy bemutatott platformon együttvéve átlagosan 28768765 ember követett a vizsgálat pillanatában.

\section{A minta klubjainak összehasonlítása működésük különböző mutatói alapján}

A részletes elemzés első részeként a klubok müködését három mutatószám mentén hasonlítottuk össze. Az elemzés középpontjába

- gazdasági eredményesség dimenzióból a „,valós jövedelemtermelö képesség",

- a pályán elért teljesítmény dimenzióból az „átlagosan meccsenként szerzett pont nagysága a hazai bajnokságban" változó, míg

- az erőforrás-gazdálkodás dimenzióból a „transzferegyenleg" került.

E mutatószámok mentén egy háromdimenziós térben helyeztük el a mintában szereplő klubokat. Ehhez az ábrázoláshoz a Microsoft Power BI felületét használtuk.

$\mathrm{Az}$ 1. ábrán látható diagram vízszintes tengelye $\mathrm{az}$ egyes klubok átlagos transzferegyenlegét, míg a függőleges tengelye az átlagos meccsenként megszerzett pontot mutatja meg. A pontok nagysága a klubok valós jövedelemtermelő képességét reprezentálják. Ezzel a három mutatóval a sportvállalkozások müködésének három fö dimenziójáról kaphatunk képet.

A negatív transzferegyenleg azt jelenti, hogy az adott klub nagyobb összegért vásárolt játékjogokat, mint amenynyiért eladott az átigazolási piacon.

Amennyiben megfigyelhető valamiféle hasonlóság az egyes klubok között, érdemes egy klaszterelemzéssel a müködésük alapján azonos klubokat egy csoportokba rendezni. 


\section{A minta 54 klubja egy háromdimenziós térben elhelyezve}

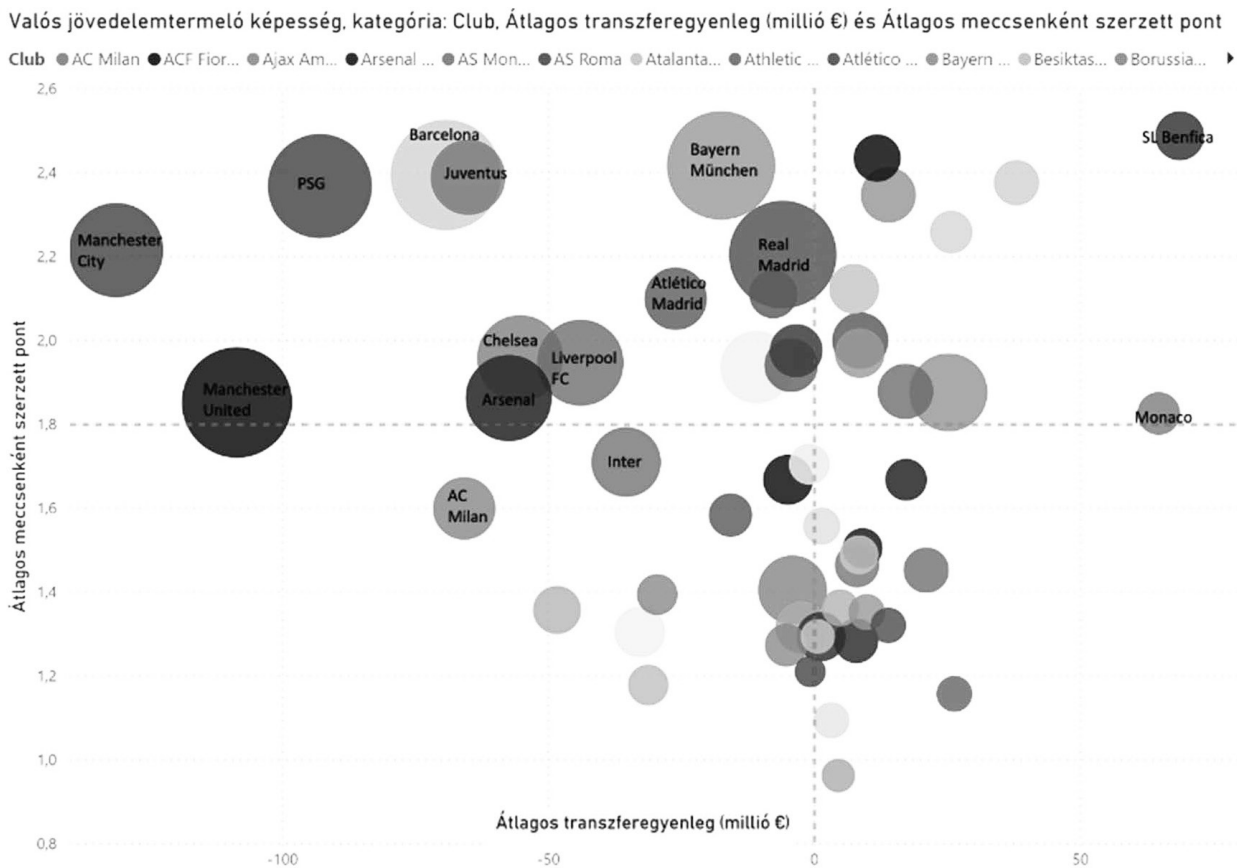

Forrás: saját szerkesztés

A SPSS program hierarchikus klaszterelemzése alapján négy nagy csoportba soroltuk be a mintában szereplő klubokat (2. ábra). Ez a négy klaszter a következő:

- nemzetközi elit,

- kihívók,

- feltörekvő bajnokok,

- versenyben maradásért küzdők.

Az első klasztert hat olyan klub alkotja, amelyek alapvetően dominálják hazájuk bajnoki küzdelmeit, és meghatározók a nemzetközi kupaküzdelmekben, mind sportszakmai, mind gazdasági eredményességi szempontból. Spanyolországból az FC Barcelona és a Real Madrid, Németországból az FC Bayern München, Franciaországból a Paris Saint-Germain, míg Angliából a Manchester United és Manchester City alkotja ezt a kimagasló klasztert. Azért is nevezhetjük e klubokat a szük nemzetközi elitnek, mivel e sportvállalkozások minden évben a bajnoki címért és a Bajnokok Ligája győzelemért küzdenek.

A második klaszterbe tartoznak az első klaszter kihívói. A müködési stratégiájukban sok hasonlóság fedezhetö fel a nemzetközi elit klubjainak stratégiával, azzal a különbséggel, hogy mindenből egy kicsivel kevesebb áll rendelkezésükre. Kevesebb a valós jövedelemtermelő képességük, ennek következtében kevesebbet költenek az átigazolási piacon. Ezekkel a szerényebb, de még mindig kimagasló lehetőségekkel igyekeznek sikereket elérni a nemzetközi kupákban és a hazai bajnokságban. Ide tartozik a Chelsea FC, Liverpool FC és az Arsenal FC Angliából, az AC Milan, az Inter és a Juventus Olaszországból, az AS Monaco Franciaországból és a Benfica Portugáliából. A minta klubjainak csoportosítása
hierarchikus klaszterelemzéssel

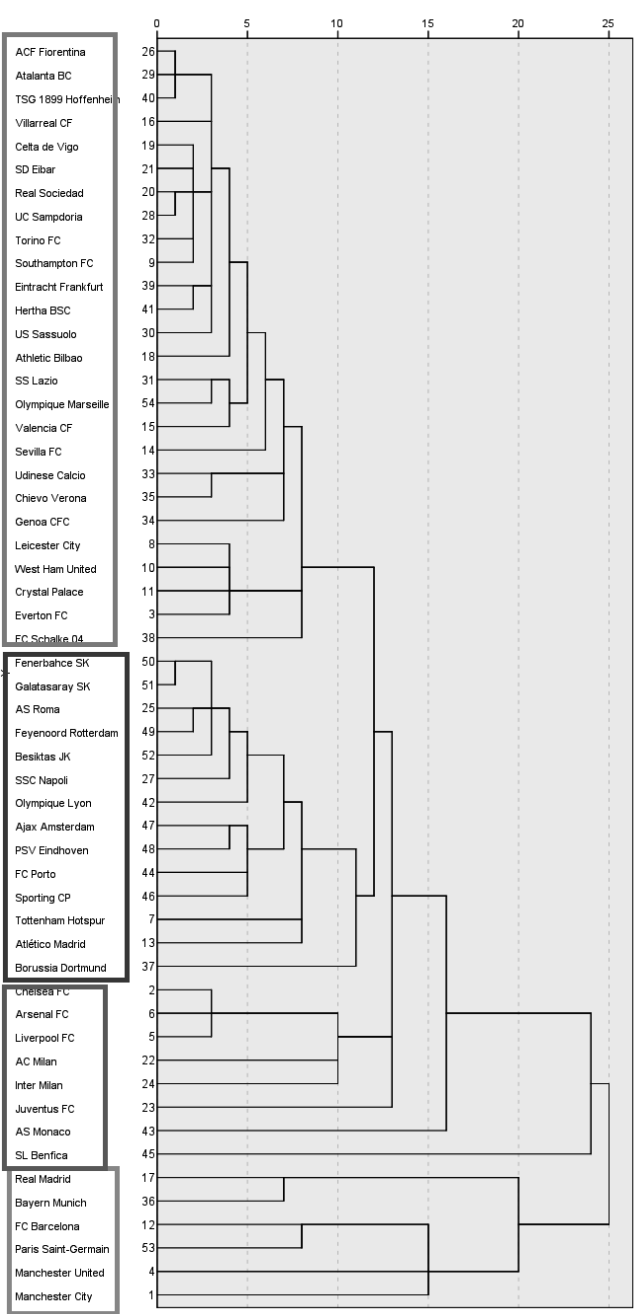

Forrás: saját szerkesztés 
Érdekességképpen megjegyeznénk, hogy az első két klaszter tizennégy klubjából öt az angol bajnokságban játszik, amiből megint csak szembetünik a Premier League klubjainak ereje.

A harmadik klaszter klubjait feltörekvő bajnokságok élklubjai alkotják. Ilyenek például a Fenerbahce SK, a Galatasaray SK, vagy a Besiktas JK Törökországból; az Ajax Amsterdam, a PSV Eindhoven és a Feyenoord Hollandiából; az FC Porto és a Sporting CP Portugáliából. Ebbe a klaszterbe tartoznak olyan klubok is, amelyek a nagyobb (angol, spanyol, olasz valamint német) bajnokságokban teljesen más stratégiával és müködési modellel igyekeznek sikereket elérni, mint az első két klaszter tagjai. Ilyenek a listából az Atlético Madrid, a Borussia Dortmund, a Tottenham Hotspur, az SSC Napoli, vagy az AS Roma.

A negyedik és egyben a legnagyobb elemszámú klasztert a nagy bajnokságok kis klubjai alkotják. E sportvállalkozások a legtöbb esetben az első osztályban maradásért küzdenek, így biztosítva folyamatos és eredményes müködésüket. A példa kedvéért említsük meg a magyar vonatkozások miatt a Hertha BSC-t vagy a TSG 1899 Hoffenheimet Németországból, vagy a Crystal Palace-t Angliából. E klubok mellett ehhez a klaszterhez tartoznak a korábbi években jól teljesítő, de cikkünk írásakor csak szenvedő nagy klubok, Németországból az FC Schalke 04 vagy Franciaországból az Olympique Marseille.

A 2. táblázatban összevetjük az egyes klaszterek átlagértékeit a három vizsgált mutató esetében.

2. táblázat

Az egyes klaszterek átlagértékei

\begin{tabular}{|c|c|c|c|}
\hline Klaszternevek & $\begin{array}{c}\text { Átlagos } \\
\text { meccsenként } \\
\text { szerzett pont }\end{array}$ & $\begin{array}{c}\text { Transzfer- } \\
\text { egyenleg } \\
\text { (millió } € \text { ) }\end{array}$ & $\begin{array}{c}\text { Valós jövede- } \\
\text { lemtermelö } \\
\text { képesség } \\
\text { (millió } € \text { ) }\end{array}$ \\
\hline Nemzetközi elit & 2,24 & $-70,93$ & 406,856 \\
\hline Kihívók & 1,97 & $-23,71$ & 165,023 \\
\hline $\begin{array}{c}\text { Feltörekvő } \\
\text { bajnokok }\end{array}$ & 2,10 & 7,41 & 87,303 \\
\hline $\begin{array}{c}\text { Versenyben ma- } \\
\text { radásért küzdők }\end{array}$ & 1,37 & $-1,50$ & 38,586 \\
\hline
\end{tabular}

Forrás: saját szerkesztés

A 2. táblázatban jelölt három változó átlagértékeinek eltérését varianciaanalízissel elemeztük a négy klaszter tekintetében.

A mérkőzésenként szerzett pontok átlagának eltérése szignifikánsnak bizonyult $\mathrm{p}<.05$ szinten a négy klaszter vonatkozásában $[\mathrm{F}(3,50)=55.114, \mathrm{p}=0.000]$. A Dunnett T3 teszttel elvégzett post hoc elemzés azt mutatta, hogy csak a Nemzetközi elit ( $\mathrm{M}=2,24, \mathrm{SD}=0,21)$ és a Feltörekvő bajnokok $(\mathrm{M}=2,10, \mathrm{SD}=0,19)$ átlagának különbsége és a Nemzetközi elit és a Kihívók $(\mathrm{M}=1,97, \mathrm{SD}=0,31)$ átlagának különbsége nem szignifikáns, minden más átlagérték szignifikánsan különbözik egymástól.

A transzferegyenlegek átlagának eltérése is szignifikáns az ANOVA-eredmények alapján $\mathrm{p}<.05$ szinten a négy klasztert illetően $[\mathrm{F}(3,50)=10.734, \mathrm{p}=0.000]$. A Dunnett T3 teszttel lefuttatott post hoc elemzés azt eredményezte, hogy csak a Nemzetközi elit $(\mathrm{M}=-70,92, \mathrm{SD}$ $=50,22)$ és a Feltörekvő bajnokok $(\mathrm{M}=7,41, \mathrm{SD}=16,83)$ átlagának különbsége szignifikáns, minden más átlagérték nem különbözik szignifikánsan egymástól.

A valós jövedelemtermelő képesség átlagának eltérése is szignifikáns $\mathrm{p}<.05$ szinten a négy klaszter esetében $[\mathrm{F}(3$, $50)=97.363, p=0.000]$. A Dunnett T3 teszttel kiszámolt post hoc elemzés alapján csak a Kihívók $(M=165,023, \mathrm{SD}$ $=89,03)$ és a Feltörekvő bajnokok $(\mathrm{M}=87,30, \mathrm{SD}=47,39)$ átlagának különbsége nem szignifikáns, minden más átlagérték szignifikánsan különbözik egymástól.

\section{Következtetések}

Talán a leglátványosabb különbség az egyes klaszterek valós jövedelemtermelő képessége között észlelhető nominálisan is. A „Nemzetközi elit” értéke majdnem két és félszer akkora, mint a „Kihívóké”, míg a „Feltörekvő bajnokok" jövedelemtermelő képessége körülbelül a fele a második klaszterének.

A „Transzferegyenleg” és az „Átlagos meccsenként szerzett pont" oszlopokból következtethetünk arra, hogy mennyire különböző az emberierőforrás-stratégiájuk az egyes klaszterek klubjainak. A „Feltörekvő bajnokok” egyenlege pozitív, mégis magas az átlagos meccsenként szerzett pont, ami magyarázható azzal, hogy ezek az egyesületek messze kiemelkednek saját bajnokságukból, így még akkor is jól teljesíthetnek, ha elveszítik legértékesebb játékosaikat. Hasonló a múködési modelljük a „Nemzetközi elit” és a „Kihívók” csoportok klubjainak ebben a két mutatóban is. Tőlük messze elmaradnak nemcsak eredményességben, hanem költésben is a „Versenyben maradásért küzdők".

Mivel a három dimenzióból kettőben találtunk szignifikáns különbségeket, ha kétdimenziósra redukáljuk a problémateret, a 3. táblázatban megjelenített mátrixba sorolhatjuk a klubokat a sikeresség és a jövedelemtermelőképesség mentén.

3. táblázat

\section{Mátrix valós jövedelemtermelő képesség és sikeresség dimenzióiban}

\begin{tabular}{|c|c|c|c|}
\hline \multirow{2}{*}{} & & \multicolumn{2}{|c|}{ Valós jövedelemtermelő képesség } \\
\cline { 3 - 4 } & & kicsi & nagy \\
\hline $\begin{array}{c}\text { Átlagos } \\
\text { meccsenként } \\
\text { szerzett pont }\end{array}$ & kevés & $\begin{array}{c}\text { Versenyben maradá- } \\
\text { sért küzdők }\end{array}$ & Kihívók \\
\cline { 2 - 4 } & sok & Feltörekvő bajnokok & Nemzetközi elit \\
\hline
\end{tabular}

Forrás: saját szerkesztés

Azt fontos megjegyezni, hogy amikor azt írjuk, hogy a valós jövedelemtermelö képesség kicsi, akkor azt a minta átlagában értjük. Valójában a „Versenyben maradásért küzdö" klubok átlagosan még így is jóval nagyobb bevételt tudnak generálni, mint bármelyik másik, listában nem szereplő európai labdarúgóklub. 
Amennyiben azonos színnel jelöljük az egyes klaszterek klubjait, akkor máris jobban átláthatóvá válik a 2 . ábra, amely így a következőképpen módosul (3. ábra). sodik klaszterhez tartozó klubok inkább néhány olcsóbb, és nem egy-kettő drága játékos megvásárlásba fektetik tőkéjüket.

3. ábra

A minta klubjai egy háromdimenziós térben, ahol azonos klaszterbe tartozó klubok azonos számértéket kaptak

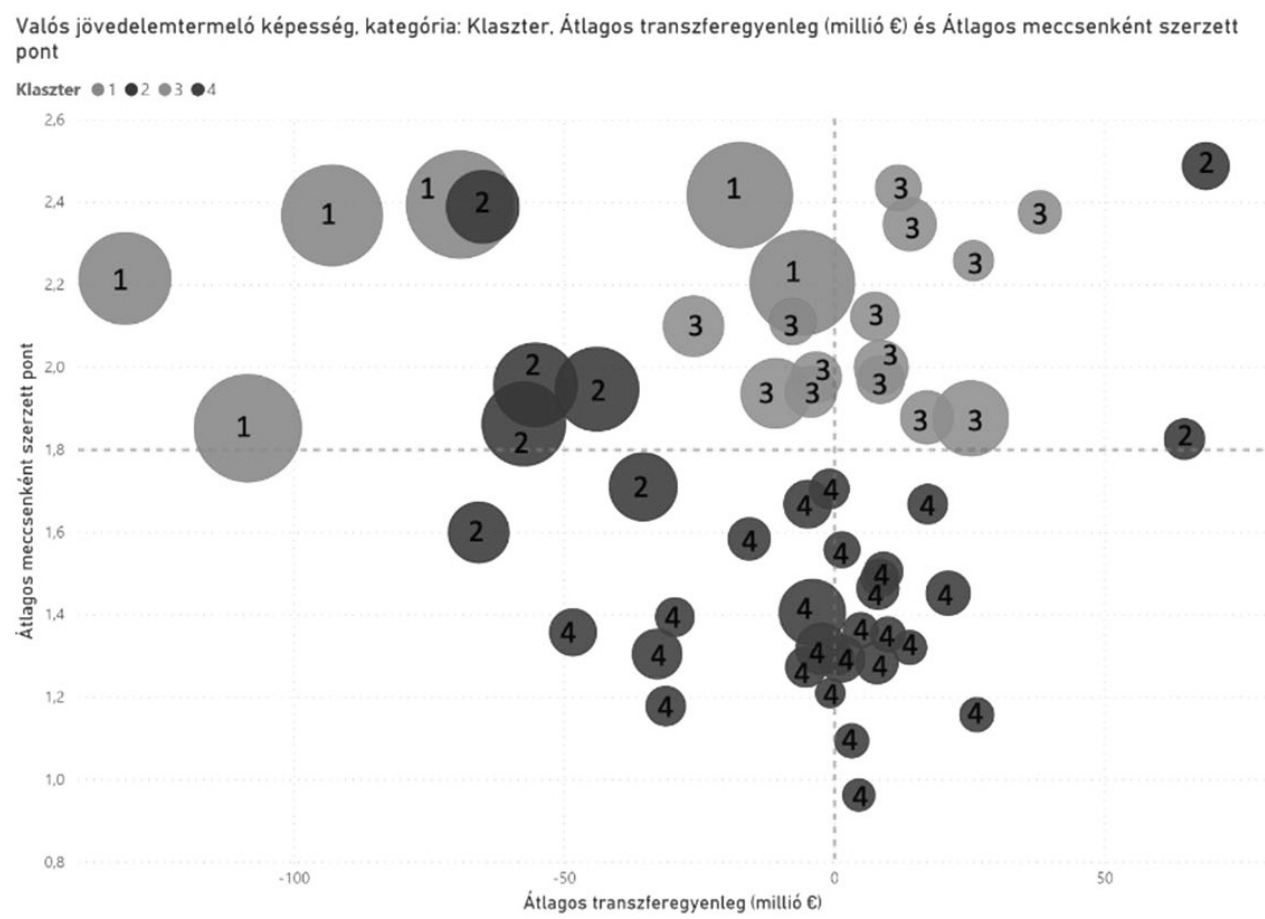

Forrás: saját szerkesztés

Gazdasági erő tekintetében messze a „Nemzetközi elit” klubjai a legerősebbek. Ennek következtében ők a legsikeresebbek mind a hazai, mind a nemzetközi kupaküzdelmekben. E klubok a legnépszerübbek a social media platformokon. Játékosvásárlással, mint erőforrás-gazdálkodással kapcsolatban az mondható el róluk, hogy kevés játékost vásárolnak, de a kiválasztott labdarúgókért sok pénzt hajlandók fizetni. Emberierőforrás-stratégiájukat a kiválasztás dominálja. A legjobb játékosok ezeknél a kluboknál játszanak, így értelemszerüen e klubok költik el a legtöbbet labdarúgóik fizetéseire.

Hasonló modellt követnek a „Kihívók” klaszter klubjai is, de mivel kevesebb forrás áll a rendelkezésükre, így a transzferegyenlegük is kevésbé negatív. Messze elmaradnak népszerüségben ezek a klubok a „Nemzetközi elit" klubjaitól. Ez igaz a játékosbérekre fordított kiadásokra is, viszont ez az érték még így is jóval magasabb, mint a maradék két klaszter klubjainál. Több-kevesebb sikerrel, de igyekeznek a hazai és nemzetközi kupaküzdelmekben is felvenni a versenyt az első csoportba tartozó klubokkal. Legmarkánsabb különbség az átigazolt játékosok darabszámánál figyelhető meg az első klaszterhez képest. Ez részben magyarázható azzal, hogy az olasz klubok (akiknél nagy a játékosmozgás egy-egy átigazolási időszak alatt) az első klaszterben még nem szerepeltek, míg a másodikban hárman is helyet kaptak. Másrészben pedig ezt a különbséget okozhatja az is, hogy a szükösebb anyagi erőforrásokkal rendelkező má-
A „Feltörekvő bajnokok” klaszter klubjainak még kevesebb forrás áll rendelkezésére, de a gyenge versenynek köszönhetően, még így is sikeresek tudnak lenni a hazai porondon. Emellett érdemes megemlíteni az emberierőforrás-stratégiájukat illetően, hogy a kiválasztás fontossága mellett nagyobb hangsúlyt fektetnek a képzés-fejlesztésre. Olcsón vásárolnak játékosokat, akiket rengeteg edzéssel és megfelelő versenyeztetéssel felkészítenek, és jó áron értékesítenek, hogy újabb és lehetőleg tehetségesebb labdarúgókat tudjanak vásárolni, így növelve bevételeiket és esélyeiket a nemzetközi kupaporondon. A nemzetközi sikerek és a hazai bajnokságban uralkodó gyenge verseny miatt az egyes klubok internetes követőszámai alacsonyak, így nem tudnak jelentős szponzorációs, valamint túl sok meccsnapi bevételt sem kitermelni.

A „Versenyben maradásért küzdők” klaszter klubjai messze a legkevesebb bevétellel rendelkeznek, így nem csoda, hogy a stratégiájuk kimerül abban, hogy valamiként az első osztályban maradjanak. Messze a legkevesebb az átlagpontszámuk. Az átigazolási piaci tevékenységükre a hektikus magatartás a jellemzö, relatíve sok játékost vásárolnak abban a reményben, hogy majd valamelyikük bent tudja tartani öket az első osztályban. Legtöbbjük számára a túlélést jelenti az első osztályú tagság, amit, ha elveszítenek, akkor a szponzorok elpártolása és a csökkenő közvetítési jogdíjak miatt csődközeli helyzetbe kerülhetnek. 


\section{Az egyes klaszterek sajátosságai}

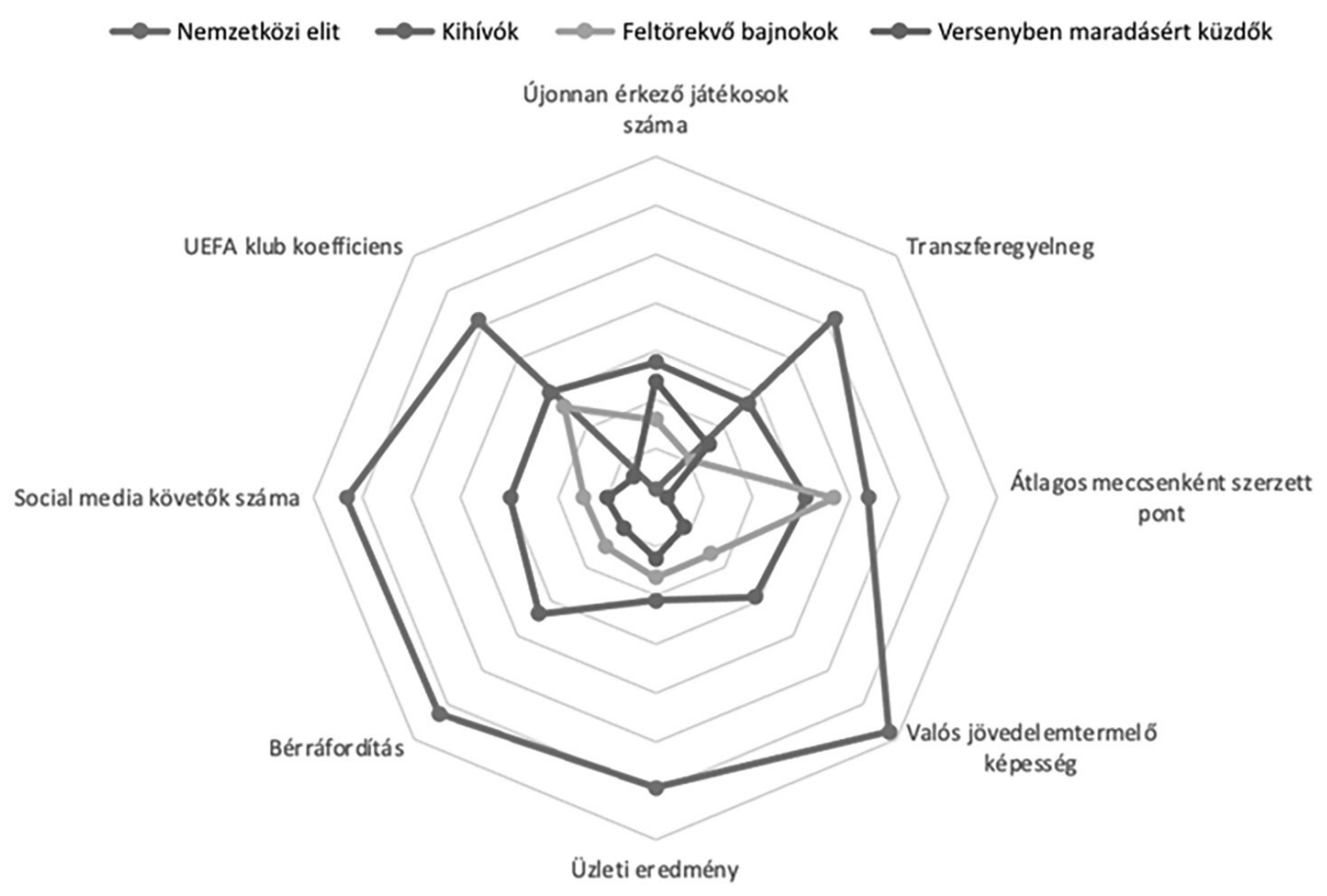

Forrás: saját szerkesztés

A 4. ábrán látható diagramról és sorokból elénk tárul, hogy a különböző klaszterek klubjai mennyire eltérő stratégiákat és müködési modelleket alkalmaznak céljaik elérése érdekében. Viszont azt is fontos megjegyezni, hogy az egy klaszterbe tartozó klubok között is lehetnek meghatározó eltérések. Különböző filozófiák, struktúrák, történelmi hátterek és az eltérő szabályozási környezet mind-mind befolyásolhatják a klubok működését és céljaik elérésének a módját. Nem beszélve az egyes klubok stratégiáiról, amelyek alapvetően határozzák meg a müködésük egyes dimenzióit.

Itt megint visszautalnánk a Szabados-féle (Szabados, 2003) stratégiatípusokra. Alapvetően két klubtípust különíthetünk el a stratégia alapján. Ezek a sikerorientált és a transzferorientált stratégiák. Előbbinél arra helyezik a hangsúlyt a vezetők, hogy olyan játékosokat szerződtessenek, akikkel eredményesebbek tudnak lenni mind a hazai bajnokságban, mind a nemzetközi kupasorozatokban. Ez megközelítőleg megegyezik a sikerkör-stratégiával. A játékosok a teljesítményük csúcsán vagy annak közelében igazolnak az adott klubhoz. Nem a jövőbeli értékesítésük a cél, hanem a teljesítményük kihasználása. A második esetben a klubok minél ügyesebb fiatal játékosok kiválasztását és azok képzését helyezik tevékenységük középpontjába. Az idő múlásával igyekeznek minél nagyobb profittal értékesíteni ezen játékosokat. Ez a felfogás hasonlít a korábban már bemutatott transzferstratégiára. Alapvetően az eltérő emberierőforrás-stratégiák alapján válik el ez a két stratégiatípust. Az ábra alapján a Manchester United és City remekül beleillik az első, míg a Benfica a második kategóriába.

Az eltérő modellek magyarázhatók a valós jövedelemtermelő képességgel is: minél nagyobb ez, annál nagyobb az a bevételtömeg, amit a közvetítési jogdíjakon felül tud előállítani a klub. Ha egy klub valós jövedelemtermelő képessége erős, akkor sok pénzt tud átigazolásokra költeni. Ha ez egy másik klub esetében kisebb, akkor ennek a sportvállalkozásnak más versenystratégiát kell folytatnia, ennek következtében az emberierőforrás-stratégiája az átigazolási piacon is más elveket követ, hiszen gyakran kényszerül arra, hogy eladja legértékesebb játékosainak játékjogát az átigazolási piacon.

Kutatásunkból kiviláglik az is, hogy elválni látszanak azok a klubok az európai klubfutball színterén, amelyek küzdenek a bajnoki címért és az európai kupaszereplésért, és azok, akik a kiesés elkerüléséért játszanak hétről hétre.

\section{Összegzés}

Az adataink arra engednek következtetni, hogy a müködés kiválasztott három mutatószáma mentén, kirajzolódnak bizonyos mintázatok az egyes klubok között. Az azonos klaszterek sportvállalkozásai hasonló mennyiségü jövedelmet állítanak elö, azonosan sikeresek a hazai bajnokságban és hasonló az átigazolási politikájuk.

A modell a jövőben még számos módon továbbfejleszthetö, amelyek közül a következőket tartunk fontosnak kiemelni. Az egyik az, hogy országonként külön-külön is érdemes lenne összevetni a müködési modelleket. Lehet-e eltérést tapasztalni a francia és az olasz klubok müködése között? A második továbbfejlesztési lehetőség a „Versenyben maradásért küzdők” klaszter tovább bontása. Látható, hogy az a legnagyobb elemszámú csoport, amelyből akár további, kisebb klasztereket is létre lehetne hozni, ahol kirajzolódhatnak érdekességek. Harmadik 
továbbfejlesztési lehetőségként azonosítottuk azt, hogy az egyes mutatók esetében ne csak az átlagokkal számoljunk, hanem vegyük figyelembe a növekedési és csökkenési ütemeket is. Az európai labdarúgóklubok üzleti modelljeinek vizsgálata relevanciával bírhat a magyar labdarúgóklubok számára is, amennyiben sportágfejlesztés vonatkozásában a nemzetközi futball vérkeringésébe történő bekapcsolódás és integrálódás mikéntjének tervezéséhez szolgáltathat inputot. A nemzetközi példák tanulmányozása segíthet jobban megérteni a nemzetközi klubfutball tendenciáit és hozzájárulhat más sportágak fejlesztéséhez is.

\section{Felhasznált irodalom}

Alaminos, D., \& Fernández, M. Á. (2019). Why do football clubs fail financially? A financial distress prediction model for European professional football industry. PLoS One, 14(12), e0225989.

https://doi.org/10.1371/journal.pone.0225989

András, K. (2003). Üzleti elemek a sportban, a labdarúgás példáján (PhD-értekezés). Budapest: Budapesti Közgazdaságtudományi és Államigazgatási Egyetem, Gazdálkodástani PhD- program.

András, K., \& Havran, Z. (2015). New Business Strategies of Football Clubs. Applied Studies in Agribusiness and Commerce, 9(1-2), 67-74. https://doi.org/10.19041/APSTRACT/2015/1-2/13

András, K., \& Havran, Z. (2016). Examination of Central and Eastern European Professional Football Clubs' Sport Success, Financial Position and Business Strategy in International Environment. In P. Trapczynski, L. Puslecki, \& M. Jarosinski (eds.), Competitiveness of CEE Economies and Businesses (pp. 197-211). Cham, Switzerland: Springer International Publishing.

Barajas, A., \& Rodriguez, P. (2010). Spanish Football Clubs Finances: Crisis and Player Salaries. International Journal of Sport Finance, 5(1), 52-66.

Franck, E. (2010). Private firm, public corporation or member's association - Governance structures in European football. International Journal of Sport Finance, 5(2), 108-127. https://doi.org/10.5167/uzh-35150

Franck, E. (2014). Financial fair play in European club football - what is it all about? (UZH Business Working Paper, (328). kiad.). Zürich, Switzerland: University of Zurich, Department of Business Administration.

https://doi.org/10.2139/ssrn.2284615

Franck, E., \& Lang, M. (2014). A theoretical analysis of the influence of money injections on risk taking in football clubs. Scottish Journal of Political Economy, 61(4), 430-454.

https://doi.org/10.1111/sjpe.12052

Garcia-del-Barrio, P., \& Rossi, G. (2020). How the UEFA Financial Fair Play regulations affect to football clubs' priorities and leagues' competitive balance? European Journal of Government and Economics, 9(2), 119-142. https://doi.org/10.17979/ejge.2020.9.2.5842
Grossmann, M. (2015). Evolutionarily stable strategies in sports contests. Journal of Sports Economics, 16(1), 108-121. https://doi.org/10.1177/1527002512470957

Kuper, S. (2009). Football Abandons the Fantasy that it Is a Business. Retrieved from https:/www.ft.com/ content/fd77a01c-aa07-11de-a3ce-00144feabdc0

Lang, M., Grossmann, M., \& Theiler, P. (2011). The sugar daddy game: how wealthy investors change competition in professional team sports. Journal of Institutional and Theoretical Economics, 167(4), 557-577. https://doi.org/10.2139/ssrn.1606043

Peeters, T., \& Szymanski, S. (2014). Financial fair play in European football. Economic Policy, 29(78), 343-390. https://doi.org/10.1111/1468-0327.12031

Reich , B., \& Szabados, G. (2000). Játékostranszferek Európában. Budapest: Vállalatgazdasági Tudományos és Oktatási Alapítvány.

Rohde, M., \& Breuer, C. (2016). The financial impact of (foreign) private investors on team investments and profits in professional football: Empirical evidence from the premier league. Applied Economics and Finance, 3(2), 243-255. https://doi.org/10.11114/aef.v3i2.1366

Rohde, M., \& Breuer, C. (2017). The market for football club investors: a review of theory and empirical evidence from professional European football. European Sport Management Quarterly, 17(3), 265-289.

https://doi.org/10.1080/16184742.2017.1279203

Schubert, M., \& Hamil, S. (2018). Financial Doping and Financial Fair Play in European Club Football Competitions. In M. Breuer, \& D. Forrest (eds.), The Palgrave Handbook on the Economics of Manipulation in Sport (Vol. 10) (pp. 135-157). Cham, Switzerland: Palgrave Macmillan.

Sener, İ., \& Karapolatgil, A. A. (2015). Rules of the game: Strategy in football industry. Procedia-Social and Behavioral Sciences, 207, 10-19.

https://doi.org/10.1016/j.sbspro.2015.10.143

Storm, R. K., \& Nielsen, K. (2012). Soft budget constraints in professional football. Sport Management Quarterly, 12(2), 183-201. https://doi.org/10.1080/16184742.2012.670660

Szabados, G. (2003). Labdarúgóklubok stratégiái. Vezetéstudomány, 34(9), 32-42.

Terrien, M., \& Andreff, W. (2020). Organisational efficiency of national football leagues in Europe. European Sport Management Quarterly, 20(2), 205224.

https://doi.org/10.1080/16184742.2019.1598455

Union of European Football Associations. (2018). Club Licensing and Financial Fair Play Regulations. Retrieved from https://documents.uefa.com/viewer/ document/MFxeqLNKelkYyh5JSafuhg

Union of European Football Associations. (2018). Club Licensing Benchmarking Report. Retrieved from https://www.uefa.com/MultimediaFiles/Download/ OfficialDocument/uefaorg/Clubl icensing/02/53/00/22/ 2530022_DOWNLOAD.pdf 
Union of European Football Associations. (2019a). Club Licensing Benchmarking Report. Retrieved from https://www.uefa.com/insideuefa/protecting-thegame/club-licensing-and-financial-fair-play/news/ newsid=2589785.html

Union of European Football Associations. (2019b). Club Ranking. Retrieved from https://www.uefa.

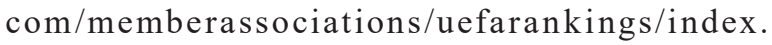
html

Wilson, R., Ramchandani, G., \& Plumley, D. (2018). Parachute payments in English football: Softening the landing or distorting the balance? Journal of Global Sport Management, 3(4), 351-368.

https://doi.org/10.1080/24704067.2018.1441740

\section{1. melléklet}

\section{A kutatásba bevont klubok listája:}

\begin{tabular}{|c|c|}
\hline Klub & Liga \\
\hline Manchester City & Premier League \\
\hline Chelsea FC & Premier League \\
\hline Everton FC & Premier League \\
\hline Manchester United & Premier League \\
\hline Liverpool FC & Premier League \\
\hline Arsenal FC & Premier League \\
\hline Tottenham Hotspur & Premier League \\
\hline Leicester City & Premier League \\
\hline Southampton FC & Premier League \\
\hline West Ham United & Premier League \\
\hline Crystal Palace & Premier League \\
\hline FC Barcelona & LaLiga \\
\hline Atlético Madrid & LaLiga \\
\hline Sevilla FC & LaLiga \\
\hline Valencia CF & LaLiga \\
\hline Villarreal CF & LaLiga \\
\hline Real Madrid & LaLiga \\
\hline Athletic Bilbao & LaLiga \\
\hline Celta de Vigo & LaLiga \\
\hline
\end{tabular}

\begin{tabular}{|c|c|}
\hline Real Sociedad & LaLiga \\
\hline SD Eibar & LaLiga \\
\hline AC Milan & Serie A \\
\hline Juventus FC & Serie A \\
\hline Inter Milan & Serie A \\
\hline AS Roma & Serie A \\
\hline ACF Fiorentina & Serie A \\
\hline SSC Napoli & Serie A \\
\hline UC Sampdoria & Serie A \\
\hline Atalanta BC & Serie A \\
\hline US Sassuolo & Serie A \\
\hline SS Lazio & Serie A \\
\hline Torino FC & Serie A \\
\hline Udinese Calcio & Serie A \\
\hline Genoa CFC & Serie A \\
\hline Chievo Verona & Serie A \\
\hline Bayern Munich & Bundesliga 1 \\
\hline Borussia Dortmund & Bundesliga 1 \\
\hline FC Schalke 04 & Bundesliga 1 \\
\hline Eintracht Frankfurt & Bundesliga 1 \\
\hline TSG 1899 Hoffenheim & Bundesliga 1 \\
\hline Hertha BSC & Bundesliga 1 \\
\hline Olympique Lyon & Ligue 1 \\
\hline AS Monaco & Ligue 1 \\
\hline FC Porto & Liga NOS \\
\hline SL Benfica & Liga NOS \\
\hline Sporting CP & Liga NOS \\
\hline Ajax Amsterdam & Eredivisie \\
\hline PSV Eindhoven & Eredivisie \\
\hline Feyenoord Rotterdam & Eredivisie \\
\hline Fenerbahce SK & Süper Lig \\
\hline Galatasaray SK & Süper Lig \\
\hline Besiktas JK & Süper Lig \\
\hline Paris Saint-Germain & Ligue 1 \\
\hline Olympique Marseille & Ligue 1 \\
\hline
\end{tabular}

